\title{
Ameliyat Öncesi ve Sonrası Dönemde Komplike Tip-A Aort Diseksiyonunda Günlük Yaşam Aktivitelerine Dayalı Hemşirelik Bakımı: Olgu Sunumu
}

\author{
Gizem Açıkgöz, ${ }^{1} \oplus$ Özlem İbrahimoğlu² \\ ${ }^{1}$ Sultan Abdülhamid Han Eğitim ve Araştırma Hastanesi, Kalp ve Damar Cerrahi Yoğun Bakım Servisi, i̇stanbul, Turkey \\ ${ }^{2}$ Bilecik Şeyh Edebali Üniversitesi, Sağlık Bilimleri Fakültesi, Hemşirelik Bölümü, Bilecik
}

\begin{abstract}
Özet
Aort diseksiyonu, aortun tabakalarının ayrılması sonucu akut bir tablo olarak ortaya çıkan, acil cerrahi müdehale gerektiren, uzun yoğun bakım süreçleri gerektirebilen mortalitesi yüksek bir hastalıktır. Günümüzde cerrahi sonrası hastane içi mortalite oranı yüksek olması sebebiyle yoğun bakım süreci uzun sürmekte ve dolayısıyla bakım gereksinimi yüksek, karmaşık ve çok yönlü olmaktadır. Bu olgu sunumunda İstanbul ilindeki bir üniversite hastanesi Kalp ve Damar Cerrahi Yoğun Bakım Servisi'nde sol karotis arteri de kapsayan Tip-A aort diseksiyon tanısıyla aort kapak replasmanı, asendan aort replasmanı ve sol karotis arter bypass grefti operasyonu yapılan hastanın ameliyat öncesi ve sonrası dönemde günlük yaşam aktivitelerine dayalı hemşirelik modeline göre uygulanan bakımın değerlendirilmesi amaçlanmıştır. Günlük yaşam aktivitelerine dayalı hemşirelik modelinin, diseksiyonlu hastanın tanılamasında etkin ve kullanılabilir bir model olarak yoğun bakım ünitelerinde çalışan ve bakım veren hemşirelere rehber olacağı düşünülmektedir.
\end{abstract}

Anahtar sözcükler: Aort diseksiyonu, günlük yaşam aktiviteleri modeli; hemşirelik, yoğun bakım.

Preoperative and Postoperative Nursing Care Based on the Model of Daily Living Activities of a Patient With Type-A Aortic Dissection: A Case Report

\begin{abstract}
Aortic dissection is an acute disease caused by the separation of the layers of the aorta, requiring urgent surgical intervention, and may require long intensive care procedures, and is highly mortal. Nowadays, due to the high in-hospital mortality rate after surgery, the intensive care process takes a long time and therefore the need for care is high, complex and versatile. The aim of this case report is to evaluate the care given according to nursing model based on preoperative and postoperative daily life activities of the patient who underwent aortic valve replacement, ascending aortic replacement, and left carotid artery bypass grafting with the diagnosis of Type-A aortic dissection including left carotid artery in a university hospital in Istanbul. The model for nursing based on a model of daily living is thought to be an effective and usable model for the nursing diagnosis of the dissected patient and will guide the nurses working in intensive care units.

Keywords: Aortic dissection; intensive care; model of daily living activities; nursing.

Cite this article as: Açıkgöz G, Ibrahimoğlu Ö. Preoperative and Postoperative Nursing Care Based on the Model of Daily Living Activities of a Patient With Type-A Aortic Dissection: A Case Report. Turk J Cardiovasc Nurs 2019;10(22):87-95.
\end{abstract}

İletişim (Correspondence): Hemş. Gizem Açıkgöz. Sultan Abdülhamid Han Eğitim ve Araştırma Hastanesi, Kalp ve Damar Cerrahi

Yoğun Bakım Servisi, İstanbul

Telefon (Phone): +90 5066884109 E-Posta (E-mail): gzmacikgoz@gmail.com

Başvuru Tarihi (Submitted Date): 11.07.2019 Kabul Tarihi (Accepted Date): 16.09.2019 
A ort diseksiyonu, aort duvarında intima tabakası ile media tabakası arasındaki yırtık sonucunda intima tabakasının kan akımının yönünde distale doğru ayrılması sonucu ortaya çıkan mortalitesi yüksek vasküler acil bir hastalıktır. Hastalığın yıllık insidansı milyonda 5-20 olarak tahmin edilmektedir. Genellikle 40 yaş üzeri erkek hastalarda görülmekle birlikte erkeklerde kadınlara göre 3 kat daha fazla ortaya çıkmaktadır. ${ }^{[1]}$ Aort diseksiyonun nedeni tam olarak bilinmemekle birlikte hipertansiyon ve ateroskleroz iki önemli risk faktörü olarak düşünülmektedir. ${ }^{[2]}$ Aort diseksiyonu için farklı sınıflamalar bulunmakla birlikte günümüzde en çok kullanılan sınıflama Stanford sınıflamasıdır. Bu sınıflama aort diseksiyonunu Tip-A ve Tip-B olmak üzere ikiye ayırmaktadır.Tip-A anatomik olarak asendan aortayı ve arcus aortayı içerir. ${ }^{[1,3]}$ Akut Tip-A diseksiyonu yüksek cerrahi morbidite ve mortalite riski ile ilişkilidir ve günümüzde cerrahi sonrası hastane içi 30 günlük mortalite oranı \%8 ile \%25 arasında değişmektedir. Hastalığın tedavisi hastanın klinik durumuna bakılmaksızın acil cerrahi işlem gerektirir. [1, 3-5] İskemik inmenin en önemli sebebi olarak görülen karotis arter diseksiyonu sıklıkla Tip-A aort diseksiyonuna sekonder olarak oluşmaktadır. ${ }^{[6]}$ Bu olgu sunumunda nadir görülen sol karotis arteri de kapsayan Tip-A aort diseksiyon tanısıyla aort kapak replasmanı, asendan aort replasmanı ve sol karotis arter bypass grefti ameliyatı yapılan hastanın ameliyat öncesi ve sonrası dönemde günlük yaşam aktivitelerine dayalı hemşirelik modeline göre uygulanan hemşirelik bakımının değerlendirilmesi amaçlanmıştır.

\section{Günlük Yaşam Aktivitelerine Dayalı Hemşirelik Modeli}

N. Roper, W. Logan ve A. T. Tierney tarafından 1970 yılında geliştirilen Günlük Yaşam Aktivitelerine Dayalı Hemşirelik Modeli, hemşirelik eğitimi ve uygulama alanlarında sıklıkla kullanılan modellerden birisidir. Model, yaşamın başlıca özelliklerini belirleyerek, bireyin yaşamını oluşturan öğeler arasındaki ilişkilerin tümünü kapsamaktadır. ${ }^{[7,8]}$ Oniki temel yaşam alanını içeren model; sadece hasta bireylere yönelik değil, sağlıklı kişiler için de sağlığın korunması ve geliştirilmesine yöneliktir. Model; yaşam süresi, yaşam aktiviteleri, yaşam aktivitelerini etkileyen faktörler, bağımlılık-bağımsızlık dizgesi ve yaşamda bireysellik olmak üzere beş ana bileşenden oluşmaktadır. ${ }^{[9]}$ Yaşam aktiviteleri ise kendi içinde güvenli çevrenin sağlanması ve sürdürülmesi, iletişim, solunum, beslenme, boşaltım, kişisel temizlik ve giyinme, vücut sıcaklığının kontrolü, hareket, çalışma ve eğlence, cinsellik, uyku ve dinlenme, ölüm olmak üzere 12 bileşenden oluşmaktadır.

\section{Olgu Sunumu}

Tanıtıcı Özellikler: 57 yaşında, Erkek
Şikayet: Iş̧ yerinde 17.40 saatlerinde başlayan sol kol ve sol bacakta ani başlayan kas gücü kaybı.

Aile Öyküsü: Kronik hastalık bulunmamakla birlikte malignite (Baba kolon Ca, tanılama 4. Evre, kemoterapi +, vefat) öyküsü mevcut.

Özgeçmiş: Yaklaşık 6 yıldır hipertansiyon mevcut. Antihipertansif ilaç kullanıyor.

\section{Yaşam Bulguları:}

- Kan basıncl; Sağ Kol:88/58mmHg, Sol Kol: $144 / 55 m m H g$

- Kalp Hızı: 61/dk

- Solunum Sayısı: 22 (spontan)

- $\mathrm{SpO}_{2}: \% 96-\mathrm{O}_{2}(-)$

\section{Fizik Muayene:}

- Bilinç açık, Glaskow Koma Skalası (GKS): 15

- Pupiller izokorik, Işık refleksi: Sağ+/Sol+, sağ gözde lateral bakış kısıtıılığı

- Nörolojik muayene: Normal, sol kolda parezi mevcut

- Periferik nabızlar: Palpable

\section{Laboratuvar Bulguları:}

- WBC: $10.05 / \mathrm{mm}^{3}$; RBC: $4.9 / \mathrm{mm}^{3} ; \mathrm{HB}: 14.3 \mathrm{~g} / \mathrm{dl} ; \mathrm{HCT}$ : $\% 43.8 ;$ PLT: $235 / \mathrm{mm}^{3}$

- Glukoz: 121 mg/dl; Üre: 33 mg/dl; Kre: 1.48mg/dl; AST: 18U/l; ALT: 22U/I

- Na: $136 \mathrm{mmol} / \mathrm{l} ; \mathrm{K}: 3.9 \mathrm{mmol} / \mathrm{l} ; \mathrm{Ca:} 9.2 \mathrm{mg} / \mathrm{dl}$

- PT/INR: 13.9sn/1.09; Troponin: 0.006

\section{İlaç Tedavisi:}

- Kandesartansileksetil 8 mg oral tb 1 X 1 (Sabah)

\section{Tıbbi Görüntüleme:}

- MR Difüzyon; BT Beyin; BT Baş, Boyun Arterleri

\section{Tıbbi Tanı:}

- Aort Diseksiyonu (Asendan aorttan başlayıp iliak arterlere kadar uzanan sol karotis arteri de içeren)

Yapılan tetkikler sonucunda Tip A aort diseksiyonu tanısı ile acil servise başvurusu sonrası 3. saatte Kalp ve Damar Cerrahi Yoğun Bakım Ünitesi (YBÜ)'ne yatırılmış ve ameliyat öncesi hazırlıkları yapılmıştır. Yoğun bakım takibi süresince acil cerrahi gereksinimi olmayan hasta bir sonraki gün sabah saatlerinde ameliyata alınmış ve 7 saat süren ameliyat sonrasında tekrar Kalp ve Damar Cerrahi YBÜ'ne alınmıştır. Ameliyat sonrası dönemde hastanın GKS: 3, hemodinami inotrop desteğinde labil olarak takip edilmiştir. Hastada ameliyat sonrası 12. günde kan kültüründe üreme tespit edilmiştir. Hastada basınç yarası gelişmemiştir. Yoğun bakım takibi süresinde sepsise bağlı hepatorenal 
yetmezlik gelişen hasta ameliyat sonrası 21. günde hayatını kaybetmiştir.

\section{Olgunun Günlük Yaşam Aktivitelerine Dayalı}

\section{Hemşirelik Modeli'ne Göre Değerlendirilmesi}

Olgunun ameliyat öncesi ve sonrası dönemde günlük yaşam aktivitelerine yönelik bağımlılık bağımsızlık döngüsü Tablo 1 ve Tablo 2'de verilmiştir.

\begin{tabular}{l|l|l|l|l|l|l|l|l|l|l|}
\hline \multirow{2}{*}{ Tab̧am aktiviteleri } & \multicolumn{6}{c|}{ Bağımlıık-Bağımsızlık Döngüsü } \\
\hline & \multicolumn{6}{c|}{$\begin{array}{c}\text { Tamamen } \\
\text { Bağımlılık }\end{array}$} & \multicolumn{6}{c|}{$\begin{array}{c}\text { Tamamen } \\
\text { Bağımsızlık }\end{array}$} \\
\hline & $\mathbf{1 0}$ & $\mathbf{9}$ & $\mathbf{8}$ & $\mathbf{7}$ & $\mathbf{6}$ & $\mathbf{5}$ & $\mathbf{4}$ & $\mathbf{3}$ & $\mathbf{2}$ & $\mathbf{1}$ \\
\hline Güvenli çevre sürdürülmesi & & & & & & & & & & \\
\hline Iletişim & & & & & & & & & & \\
\hline Solunum & & & & & & & & & & \\
\hline Beslenme & & & & & & & & & & \\
\hline Boşaltım & & & & & & & & & & \\
\hline Kişisel temizlik ve giyinme & & & & & & & & & & \\
\hline Vücut sıcaklığını kontrolü & & & & & & & & & & \\
\hline Hareket & & & & & & & & & & \\
\hline Çalışma ve eğlenme & & & & & & & & & & \\
\hline Cinsellik & & & & & & & & & & \\
\hline Uyku ve dinlenme & & & & & & & & & \\
\hline Ölüm & & & & & & & & & & \\
\hline
\end{tabular}

Tablo 2. Hastanın ameliyat sonrası bağımlılık-bağımsızlık döngüsü

\begin{tabular}{l|l|l|l|l|l|l|l|l|l|l|}
\hline \multirow{2}{*}{ Yaşam aktiviteleri } & \multicolumn{6}{c}{ Bağımlılık-Bağımsızlık Döngüsü } \\
\hline & \multicolumn{6}{c|}{$\begin{array}{c}\text { Tamamen } \\
\text { Bağımlılı }\end{array}$} & \multicolumn{6}{c}{$\begin{array}{c}\text { Tamamen } \\
\text { Bağımsızlık }\end{array}$} \\
\hline & $\mathbf{1 0}$ & $\mathbf{9}$ & $\mathbf{8}$ & $\mathbf{7}$ & $\mathbf{6}$ & $\mathbf{5}$ & $\mathbf{4}$ & $\mathbf{3}$ & $\mathbf{2}$ & $\mathbf{1}$ \\
\hline Güvenli çevre sürdürülmesi & & & & & & & & & & \\
\hline İletişim & & & & & & & & & & \\
\hline Solunum & & & & & & & & & & \\
\hline Beslenme & & & & & & & & & & \\
\hline Boşaltım & & & & & & & & & & \\
\hline Kişisel temizlik ve giyinme & & & & & & & & & & \\
\hline Vücut sıcaklığını kontrolü & & & & & & & & & & \\
\hline Hareket & & & & & & & & & & \\
\hline Çalışma ve eğlenme & & & & & & & & & & \\
\hline Cinsellik & & & & & & & & & & \\
\hline Uyku ve dinlenme & & & & & & & & & & \\
\hline Ölüm & & & & & & & & & \\
\hline
\end{tabular}

\section{Yaşam Süresi}

Yaşam süresi, modelin en önemli parçalarından birisidir. Yaşam, intrauterin dönem ile başlar ve ölüme kadar sürer. Insan yaşamı boyunca sürekli değişim içindedir ve yaşamın her döneminde fiziksel, psikolojik, sosyokültürel, çevresel, politik ve ekonomik süreçlerden etkilenir. ${ }^{[10]}$

Diseksiyon için ileri yaş önemli risk faktörü olmasına rağmen literatürde hiçbir risk faktörü olmayan olgular da bulunmaktadır. ${ }^{[1,2]}$ Hasta, yaşam süresinin orta yaş evresindedir ve yaşı diseksiyon için tek başına risk faktörü oluşturmamaktadır. Hasta, ameliyat öncesi dönemde yaşamı tehdit eden hastalığının ve ameliyat sonrası yüksek komplikasyon riskleri ve yüksek düzey yoğun bakım gereksiniminin olması sebebiyle mortalite açısından yüksek risk taşımaktadır.

\section{Günlük Yaşam Aktiviteleri}

\subsection{Güvenli Çevrenin Sağlanması ve Sürdürülmesi}

Güvenli çevre; hem fiziksel, hem ruhsal, hem de sosyal yönden güvenli ortam demektir. ${ }^{[11]}$ Bireylerin yaşamlarını devam ettirebilmeleri için güvenli bir ortama gereksinimleri vardır. Hastane ortamında güvenli çevrenin sağlanması ve sürdürülmesine yönelik girişimler, bireyin sağlık kuruluşuna girdiği anda başlamaktadır. ${ }^{[7,12]}$

Ameliyat öncesi hastanın herhangi bir duyusal sorunu olmamasına karşın, ciddi bir hastalık tanısının olması, ameliyat öncesi YBÜ'nde takip, tedavi ve bakımının sürdürülmesi, invaziv girişimler, monitörizasyon ve hareket kısıtlılığı; ameliyat sonrası dönemde ise bu tabloya eşlik eden cerrahi ekipman varlığı ve sedasyon altında duyuların baskılanması enfeksiyon riskine ve doku bütünlüğünde bozulmalara yol açmıştır. Bu süreçte olgunun; hastalığa, cerrahi girişime ve uygulanan hemşirelik girişimlerine bağlı ağrı deneyimi olmuştur. Hastanın bu aktiviteyle ilişkili bağımsızlığı ameliyat öncesi 5/10; ameliyat sonrası 1/10 olarak değerlendirilmiştir.

\section{Hemşirelik Tanısı}

- Cerrahi insizyon ve kateter varlığına bağlı enfeksiyon riski.

\section{Hedef}

- Hastada enfeksiyon bulgularının gözlenmemesi.

\section{Girişim:}

- Hastanın enfeksiyon belirti ve bulguları (vücut sıcaklığında artış, insizyon ve girişim bölgelerinde lokal sıcaklık artışı, kızarıklık, kötü koku) yönünden saatlik olarak değerlendirilmesi.

- Hastanın enfeksiyona yönelik laboratuvar bulgularının günlük olarak kontrol edilmesi. 
- Cerrahi insizyon bölgeleri ve kateter bölgelerinin pansumanının herhangi bir enfeksiyon bulgusuna rastlanmadıkça ilk 3 gün ve günlük olarak yapılması, 3. gün sonunda yara yerlerinin açık bırakılması.

- Endotrakeal aspirasyonun steril koşullarda sekresyon artışı olmadığı taktirde 4 x 1, sekresyon artışı olması durumunda ihtiyaç durumunda daha sıklıkla yapılması.

- Hastanın vücut banyosunun günlük, diğer bakımlarının (sonda ve kateter bakımı, el-yüz-ağız bakımı) günde 2 kez yapılması.

\section{Değerlendirme:}

- Hastada ameliyat sonrası 12. günde enfeksiyon gelişti. *Hastaya enfeksiyon riski tanısının yanı sıra akut ağrı, düşme riski ve kanama riski tanılarına yönelik hemşirelik girişimleri uygulanmıştır.

\section{2. İletişim}

İletişim, insan yaşamının ve ilişkisinin temel koşuludur. Sağlıklı bir insanın yaşamında gerekli olan verbal yada nonverbal iletişim hastane/yoğun bakım ünitesi gibi farklı bir ortama uyum söz konusu olduğunda önemli bir aktivite olmaktadır. ${ }^{[9]}$

Ameliyat öncesi iletişim aktivitesiyle ilişkili herhangi bir bireysel engeli bulunmayan hastanın hemodinamik stabilite gereksinimi olması sebebiyle iletişimi mümkün olduğunca kısıtlanmış, hastayı fiziksel ve psikolojik stresörlerden korumak amacıyla ziyaretçi kısıtlaması yapılmıştır. Hasta, ameliyat sonrası dönemde bilincinin kapalı olması sebebiyle iletişime kapalı hale gelmiştir. Hastanın tepkileri ağııı uyarana verdiği geri çekmeli yanıt ile sınırlı kalmıştır. Hastanın bu aktiviteyle ilişkili bağımsızlığı ameliyat öncesi 8/10, ameliyat sonrası 1/10 olarak değerlendirilmiştir.

\section{Hemşirelik Tanısı:}

- Ameliyat sonrası dönemde bilincin kapalı olmasına bağlı sözel iletişimde bozulma.

\section{Hedef:}

- Hastanın sözel iletişimde bozulmaya bağlı kendini ifade edememenin olumsuz sonuçlarını en az düzeyde yaşaması.

\section{Girişim:}

- Hastanın iletişim kuramaması sebebiyle kendini ifade edemediği durumlar ve değişiklikler ile ilişkili vücut tepkilerinin dikkatle gözlemlenmesi,

- Hastanın yaşam bulgularındaki değişimlerin, kendini ifade edememe durumu ile ilişkili olabileceğinin göz önünde bulundurulması,

- Birinci derece yakınlarının hastayı ziyaret etmesine teş- vik edilmesi,

- Birinci derece yakınlarının yardımları ile hastanın bireysel istek ve gereksinimlerinin belirlenmeye çalışılması

\section{Değerlendirme:}

- Hastanın kendini ifade edememesi sebebiyle gözlemsel olarak iletişim kurularak hastanın verdiği tepkilere göre gereksinimleri karşılandı.

\subsection{Solunum}

Solunum; bireyin doğumu ile başlayan ve ölümü ile son bulan hayati bir aktivitedir. YBÜ'nde tedavi gören hastalarda solunum aktivitesi ile ilgili sorunlar sıklıkla görülebilmekte ve bu durum tüm yaşam aktivitelerini olumsuz olarak etkilemektedir. ${ }^{[12]}$

Ameliyat öncesi solunum aktivitesiyle ilgili herhangi bir bireysel engeli bulunmayan hasta doku perfüzyonunun üst düzeyde olması için düşük doz oksijen desteğinde takip edilmiştir. Ameliyat sonrası dönemde spontan solunumu gelen hasta mekanik ventilatörde senkronize aralıklı zorunlu ventilasyon (Senkronize Intermitten Mandatory Ventilation-SIMV) modunda yüksek bağımlılıkta 21 gün takip edilmiştir. Hasta yoğun bakım ünitesinde yaşamını yitirene kadar entübe olarak kalmıştır. Hastanın bu aktiviteyle ilişkili bağımsızlığı ameliyat öncesi 9/10, ameliyat sonrası 1/10 olarak değerlendirilmiştir.

\section{Hemşirelik Tanısı:}

- Sekresyon artışına bağlı hava yolu açıklığında yetersizlik.

\section{Hedef:}

- Hastanın hava yolu açıklığının sağlanarak etkili ve yeterli solunumun sürdürülmesi.

\section{Girişim:}

- Hastanın solunum hızı, solunum sesleri, sekresyon özelliğinin değerlendirilmesi.

- Hastaya fowler - semifowler pozisyon verilmesi.

- Postural drenaj uygulanması.

- Sekresyon miktarına göre en az 4x1 endotrakeal aspirasyon yapılması.

- Yeterli hidrasyonun sağlanması.

- Hekim istemi ile bronkodilatör ve ekspektoran ilaçların uygulanması.

\section{Değerlendirme:}

- Hastanın hava yolu açıklığı sağlandı.

- Hastanın solunum parametrelerinin etkili ve yeterli solunumu sağlayan değer aralığında olduğu gözlendi.

*Hastaya hava yolu açıklığında yetersizlik riski tanısının yanı sıra spontan solunumda bozulma, aspirasyon ve gaz alış- 
verişinde bozulma risklerine yönelik hemşirelik girişimleri uygulanmıştır.

\subsection{Beslenme}

Sağlığın sürdürülmesi, geliştirilmesi ve hastalıkların önlenmesinde önemli olan beslenme, temel gereksinimlerdendir. ${ }^{[12]}$ Yoğun bakım hastaları malnütrisyona girmeye oldukça yatkın olup bu durum yoğun bakımda kalış süresinin uzamasına ve morbidite ve mortalitede artışa neden olmaktadır. ${ }^{[13]}$

Ameliyat öncesi hastanın beslenme aktivitesiyle ilgili bireysel bir engeli bulunmamakla birlikte, ameliyat hazırlıkları sürecinde acil olarak ameliyata alınma intimaline karşın oral alımı sonlandırımış, bu süreçte parenteral sıvı desteği planlanmıştır. Hasta ameliyat sonrası dönemde entübe olması sebebiyle oral alıma başlanmamıştır. Bu süreçte ilk yedi gün parenteral beslenen hasta 5 . günden sonra parenteral beslenmenin yanına nazogastrik sonda ile beslenme eklenmiştir. Hastanın bu aktiviteyle ilişkili bağımsızlığı ameliyat öncesi 7/10; ameliyat sonrası 1/10 olarak değerlendirilmiştir.

\section{Hemşirelik Tanısı:}

- Entübasyona bağlı oral alımın olmaması sebebiyle beden gereksiniminden az beslenme riski.

\section{Hedef:}

- Hastanın metabolik gereksinimlerine göre beslenmesi.

- Hastanın kilo kaybı yaşamaması.

\section{Girişim:}

- Hastanın günlük aldığı çıkardığı takibi (AÇT) ve kilo takibi yapılması.

- Nütrisyon hemşiresi ve diyetisyen işbirliğinde hastanın kilosuna ve metabolik gereksinimlerine göre planlanan beslenmenin uygun olan beslenme yolu ile sağlanması

- Malnütrisyon belirti ve bulgularının izlemesi.

- Hekim istemi ile beslenme destek ürünlerinin uygulanması.

\section{Değerlendirme:}

- Hasta kilo kaybı yaşamadı.

- Hastanın günlük kalori ihtiyacı ve besin gereksinimine uygun beslenmesi sağlandı.

*Hastaya beden gereksiniminde az beslenme riski tanısının yanı sıra sıvı volüm dengesizliği riski tanısına yönelik hemşirelik girişimleri uygulanmıştır.

\subsection{Boşaltım}

Sindirim ve üriner sistemin fizyolojik sonuçlarını oluşturan boşaltım, yaşamın sürdürülmesi için gerekli temel ve mahrem aktivitedir. ${ }^{[12]}$ YBÜ'ndeki bireylerin çoğu boşaltım aktivitesini yardımcı araçlarla bağımlı şekilde gerçekleştirmektedir.

Ameliyat öncesi boşaltım aktivitesiyle ilgili herhangi bir bireysel engeli bulunmayan hastanın yatak istirahati sebebiyle üriner kateteri bulunmaktadır ve defekasyon ihtiyacı için hasta bezi kullanılmıştır. Ameliyat hazırlığı olarak hastaya lavman uygulaması yapılmıştır. Ameliyat öncesi ve sonrası dönemde YBÜ'nde oral alımının olmaması, yatak istirahatı, kullanılan ilaçlar ve immobilite bağırsak boşaltımını olumsuz etkilemiştir. Ameliyat sonrası 5. günde nazogastrik beslenmeye geçilmesi ile beslenmenin 4. gününde defekasyonu olmuştur. Yatağa bağımlı olan hastanın yoğun bakım ünitesinde takip edildiği süre içerisinde idrar boşaltımı foley sonda ile, defekasyonu hasta yatağında hasta alt bezi ile sağlanmıştır. Hastanın bu aktiviteyle ilişkili bağımsızlığı ameliyat öncesi 5/10; ameliyat sonrası 1/10 olarak değerlendirilmiştir.

\section{Hemşirelik Tanısı:}

- Nazogastrik solüsyonla beslenmeye bağlı diyare riski.

Hedef:

- Hastanın normal sıklıkta ve kıvamda gaita yapması.

\section{Girişim:}

- Risk faktörlerinin kontrol altına alınması

- Nazogastrik beslenme solüsyonunun vücut sıcaklığına getirilerek hastanın beslenmesi

- Hastanın besinleri tolere edip etmediğinin belirli aralıklarla kontrol edilmesi

- AÇT yapılması

\section{Değerlendirme:}

- Hastada diyare gelişmedi.

*Hastaya diyare riski tanısı yanı sıra idrar boşaltımında bozulma ve konstipasyon riski tanılarına yönelik hemşirelik girişimleri uygulanmıştır.

\subsection{Kişisel Temizlik ve Giyinme}

$\mathrm{Bu}$ aktivite, bireylerin temiz ve iyi görünümde olmalarının yanı sıra özgüven ve sorumluluklarının yerine getirilmesine yardımcı olan, cinsel ifadelerini yansıtan ve sözsüz iletişim yollarından biri olan bir aktivitedir. ${ }^{[12]}$

Ameliyat öncesi kişisel temizlik ve giyinme aktivitesiyle ilgili herhangi bir bireysel engeli bulunmamakla ve dış görünüşü temiz olmakla birlikte, hastanın YBÜ'nde tüm kıyafetleri çıkarılmıştır. Ameliyat hazırlıkları kapsamında tüm vücut tıraşı ve vücut silme banyosu yapılmıştır. Ameliyat sonrası dönemde bilinci kapalı olan hastanın bireysel temizliği hemşireler tarafından yapılmıştır. Hastanın bu aktiviteyle ilişkili bağımsızlığı ameliyat öncesi 4/10; ameliyat sonrası 
1/10 olarak değerlendirilmiştir.

\section{Hemşirelik Tanısı:}

- Ameliyat sonrası dönemde bilincin kapalı olmasına bağlı bireysel hijyende yetersizlik.

\section{Hedef:}

- Hastanın bireysel hijyen gereksinimlerinin sağlık çalışanları tarafından karşılanması.

- Hastanın bireysel hijyen gereksinimlerine ilişkin yetersizlik yaşamaması.

\section{Girişim:}

- Hastanın bireysel hijyen gereksinimlerinin günlük olarak değerlendirilmesi.

- Hastanın vücut banyosunun günlük olarak yaptırılması.

- Hastanın çarşaflarının günlük olarak ve ihtiyaç durumunda değiştirilmesi.

- Hastanın vücut, yüz, ağız bakımının günde iki kez ve ihtiyaç durumunda yapılması.

- Hastanın sakal tıraşının haftada iki kez yaptırılması.

\section{Değerlendirme:}

- Hastanın bireysel hijyen gereksinimleri sağlık personeli tarafından karşılandı.

- Hasta bireysel hijyen gereksinimlerine ilişkin yetersizlik yaşamadı.

\subsection{Vücut Sıcaklığının Kontrolü}

Sağlıklı birey vücut sıcaklığının kontrolünü yerine getirebilirken, hasta bireyler giyinme, ortam ısısını sağlama, havalandırma, vücut sıcaklığını ölçme ve gerekli girişimleri uygulamada başkasına bağımlıdır. ${ }^{[12]}$

Hastanın ameliyat öncesi vücut sıcaklığının kontrolü aktivitesiyle ilgili herhangi bir bireysel engeli bulunmamakta ve vücut sıcaklığı normal değer aralığındadır. Hastaya, YBÜ'nin sıcaklığının düşük olması, hastanın üzerinde giysi olmaması ve parenteral sıvı infüzyonları hipotermi riskine; hastane infeksiyonları ise hipertermi riskine yol açabileceği için bu risklere ilişkin hemşirelik girişimleri yapılmıştır. Ameliyat sonrası erken dönemde herhangi bir vücut sıcaklığı değişimi olmazken 16 . gün gelişen enfeksiyon sebebiyle $38.7^{\circ} \mathrm{C}^{\prime} \mathrm{a}$ ulaşan hipertermi görülmüştür. Hastanın bu aktiviteyle ilişkili bağımsızlığı ameliyat öncesi 5/10; ameliyat sonrası 1/10 olarak değerlendirilmiştir.

\section{Hemşirelik Tanısı:}

- Hastada gelişen enfeksiyona bağlı hipertermi.

\section{Hedef:}

- Hastanın vücut sıcaklığııın $36,4-37,5^{\circ} \mathrm{C}$ aralığında olması.
- Hastada hipertermi belirti ve bulgularının gözlenmemesi.

\section{Girişim:}

- Hastanın tüm yaşam bulgularının saatlik olarak, vücut sıcaklığının hipertermi durumunda 30 dakikada bir ölçülmesi.

- Vücut sıcaklığının $38^{\circ} \mathrm{C}^{\prime} ı$ üzerine çıkması durumunda kan kültürü tekrarı yapılması.

- Hipertermi durumunda soğuk uygulama yapılması.

- Vücut sıvı kaybının önlenmesi için intravenöz (IV) sıvı replasmanının sağlanması.

- Hekim istemi doğrultusunda enfeksiyon ve hipertermiye yönelik tedavinin uygulanması.

\section{Değerlendirme:}

- Hastanın vücut sıcaklığı sıklıkla subfevril ortalama günde $3 \mathrm{kez} 37.5^{\circ} \mathrm{C}^{\prime}$ In üzerinde seyretti.

- Hipertermi gelişmesi durumunda hastanın vücut sıcakIığının ortalama bir saatlik sürede normal değer aralığında ya da subfevril düzeyde olması sağlandı.

- Vücut sıcaklığının $38^{\circ} \mathrm{C}^{\prime} ı$ üzerine çıkması durumunda kan kültürü tekrarı yapıldı.

\subsection{Hareket}

Hareket, bağımlılık bağımsızlık dizgisiyle yakından ilgilidir ve bireyin diğer yaşam aktivitelerini yerine getirme durumunu doğrudan etkilemektedir. ${ }^{[12]}$

Ameliyat öncesi hasta kesin yatak istirahatına alınmış ve yatak içi hareketleri sınırlandırılmıştır. Ameliyat sonrası hastanın bilincinin kapalı olması nedeniyle hareket aktivitesi kısıtlanmıştır. Hastaya pozisyon değişikliği ve eklem hareket açıklığı (Range of Motion-ROM) egzersizleri uygulanmış, fizik tedavi desteği sağlanmıştır. Hastanın bu aktiviteyle ilişkili bağımsızığı ameliyat öncesi 4/10; ameliyat sonrası 1/10 olarak değerlendirilmiştir.

\section{Hemşirelik Tanısı:}

- Sürekli yatak istirahati ve bilincin kapalı olması sebebiyle hareket yetersizliğine bağlı doku bütünlüğünde bozulma riski.

\section{Hedef:}

- Hastanın doku bütünlüğünde bozulma gözlenmemesi.

- Hastanın belirli aralıklarla yatak içinde hareketinin sağlanması.

\section{Girişim:}

- Hastanın basınç yarası riskinin günlük olarak ya da genel durumunda oluşan her bir değişiklik durumunda basınç yarası değerlendirme ölçekleriyle değerlendirilmesi.

- Hastaya düzenli olarak en az iki saatte bir pozisyon veril- 
mesi ve ROM egzersizlerinin uygulanması.

- Hastanın vücudundaki basınç bölgelerinin saatlik olarak ve pozisyon verilmesi sırasında yaralanma yönünden gözlenmesi.

- Hastanın yatak çarşaflarının kuru ve gergin olmasının sağlanması.

- Hastanın cildinin temiz ve kuru olmasının sağlanması.

- Hastanın beslenmesinin doku beslenmesi en iyi sağlanacak şekilde düzenlenmesi.

- Basınç yarasını önlemeye yönelik ekipmanların (pozisyon pedleri, havalı yatak vb.) kullanılması.

\section{Değerlendirme:}

- Hastada basınç yarası gözlenmedi.

- Hastanın yatak içinde mümkün olan düzeyde hareket ettirilmesi sağlandı.

*Hastaya doku bütünlüğünde bozulma tanısı riski yanı sıra aktivite intoleransı ve doku perfüzyonunda bozulma riski tanılarına yönelik hemşirelik girişimleri uygulanmıştır.

\section{9. Çalışma ve Eğlence}

Çalışma ve eğlence; sağlıklı bireyin, geçimini sağlama ve zamanını değerlendirmesi için bir uğraş edinip çalışması ve geriye kalan zamanını ise kendisine zevk verecek türde bir aktivite ile değerlendirmesini ifade etmektedir. ${ }^{[12]}$

Hastanın ameliyat öncesi çalışma ve eğlence aktivitesi ile ilgili herhangi bir bireysel engeli bulunmamaktadır. Ameliyat öncesi YBÜ'nde anksiyetesinin azalmasına destek olmak amacıyla hastanın isteği ile kitap okuması sağlanmıştır. Ailesinin kendisini ziyaret etmesinden memnun olduğunu belirtmiştir. YBÜ'nde olduğu sürede ziyaretçi kısıtlaması, cerrahi alanın genişliği, cerrahi ekipmanların varlığı hastanın hareketlerini kısıtlayarak konforunu bozmuştur. Hastanın bu aktiviteyle ilişkili bağımsızlığı ameliyat öncesi dönemde 3/10; ameliyat sonrası dönemde 1/10 olarak değerlendirilmiştir.

*Hastaya ameliyat sonrası dönemde sosyal izolasyon tanısı konulmuş fakat hastanın tıbbi durumu sebebiyle herhangi bir hemşirelik girişimi uygulanmamıştır.

\subsection{Cinsellik}

Cinsellik; fiziksel görünüş, giyim tarzı, iletişim ve kişilerarası ilişkiler ile yakından ilişkilidir. ${ }^{[12]}$

Hastanın ameliyat öncesi cinsellik aktivitesiyle ilgili herhangi bir bireysel engeli bulunmadığını hastanın giyim tarzı, aile ve sosyal çevresi ile ilişkisi yansıtmaktaydı. Ameliyat öncesi idrar sondası olan hastada, normal olmayan kızarıklık, kanama veya akıntı gözlenmemiştir. Hastanın bu aktiviteyle ilişkili bağımsızlığı ameliyat öncesi 2/10; ameliyat sonrası
1/10 olarak değerlendirilmiştir.

*Hastaya cinsel yaşamda değişiklik tanısı konulmuş fakat hastanın tıbbi durumu sebebiyle herhangi bir hemşirelik girişimi uygulanmamıştır.

\subsection{Uyku ve dinlenme}

Hücresel büyüme ve yenilenme ile stresle başetmede önemli rol oynayan uyku insan yaşamının temel ve vazgeçilmez aktivitelerindendir. ${ }^{[12,14,15]}$ Yoğun bakımın kendine özel çevresindeki yüksek düzeyde ses ve ışık, tanı ve tedavi işlemleri ve altta yatan hastalıklar nedeniyle hastalarda uyku problemleri görülebilmektedir.

Hastanın ameliyat öncesi uyku ve dinlenme aktivitesiyle ilgili herhangi bir bireysel engeli bulunmamaktadır. Hastada ameliyat öncesi YBÜ'ndeki gürültü ve aydınlatmadan dolayı uyku biçiminde bozulma gözlenmiş, ameliyat sonrası bilinci kapalı olduğu için değerlendirilememiştir. Hastanın bu aktiviteyle ilişkili bağımsızlığı ameliyat öncesi 7/10; ameliyat sonrası 1/10 olarak değerlendirilmiştir

*Hastaya uyku biçiminde bozulma tanısı konulmuş fakat hastanın bilincinin kapalı olması sebebiyle herhangi bir hemşirelik girişimi uygulanmamıştır.

\subsection{2. Ölüm}

Ölüm; yaşamın sonunu ifade eder ve diğer tüm süreçlerin etkilendiği bir durumdur. Bu sebeple yaşam aktiviteleri açısından da önemli bir kavramdır. ${ }^{[10,12]}$

Hastanın ameliyat öncesi yaşamı tehdit hastalık sebebiyle ve ameliyat sonrası majör cerrahi, komplikasyon riskleri ve yüksek düzey yoğun bakım gereksinimi sebebiyle mortalite açısından yüksek risk taşımaktadır. Bütün bu riskler aile bireylerini endişelendirmiş, hastanın hayatını kaybetmesinden korktuklarını ifade etmişlerdir. Hasta ise kendisi için ölümü doğal kabul ettiğini ifade etmiştir. Ameliyat sonrası 21. günde hasta yaşamını yitirmiştir. Hastanın bu aktiviteyle ilişkili risk düzeyi ameliyat öncesi Euroscore ile değerlendirilerek 3/10, ameliyat sonrası APACHE II ile değerlendirilerek 4/10 olarak belirlenmiştir. Hasta ameliyat sonrası 21. günde sepsise bağlı hepatorenal yetmezlik sebebi ile hayatını kaybetmiştir.

\section{Yaşam Aktivitelerini Etkileyen Faktörler}

Yaşam aktivitelerini etkileyen faktörler; fiziksel, psikolojik, sosyokültürel, çevresel, politik ve ekonomik faktörlerdir.[8]

Biyolojik faktörler: Tip-A aort diseksiyonu, majör cerrahi, cerrahi ekipmanlar, ağrı, uykusuzluk, hareket kısıtılığı ve beslenme, solunum, boşaltım fonksiyonlarındaki değişimler.

Psikolojik faktörler: Hastanede yatma, stres, anksiyete, aileden uzakta olma. 
Sosyokültürel faktörler: Hasta ve ailesinin sosyokültürel özellikleri bakım ve tedaviyi olumsuz yönde etkilememiştir.

Çevresel faktörler: YBÜ'nde tedavi alma, gürültü, aydınlatma, oda ısısı, ziyaretçi kısıtlaması hastanın yaşam aktivitelerini olumsuz etkilemiştir.

Politik ve ekonomik faktörler: Hastanın sosyal güvencesinin olması, ailenin geçim sıkıntısı çekmediğini ifade etmesi ekonomik sorun olmadığını göstermiştir.

\section{Bağımlılık-Bağımsızlık Dizgesi}

Bireyin yaşam alanı içindeki yeri ve yaşam aktivitelerine katılım biçimi, her bir yaşam aktivitesindeki bağımlılık-bağımsızlık dizgisini oluşturmaktadır. ${ }^{[8]}$

Hastanın bağımlılık-bağımsızlık dizgesi ameliyat öncesi ve sonrası dönemlerde yaşam aktivitelerine göre farklılık göstermiştir.

\section{Yaşamda Bireysellik}

Bireysellik, modelin diğer parçalarının yaşam aktiviteleri üzerindeki etkileri ve bunlar arasındaki karşılıklı etkileşimin bir sonucu olarak ortaya çıkar. ${ }^{[10]}$ Her birey tüm yaşam aktivitelerini yaşamları sürecinde farklı şekilde deneyimler. ${ }^{[12]}$

Yaşam süresinin orta yaş evresinde olan olgu, yaşam aktivitelerini bağımlı/bağımsız olarak yerine getirirken çeşitli biyolojik, psikolojik, sosyokültürel, çevresel ve ekonomik faktörlerden etkilenmektedir. Modelin yaşamda bireysellik öğesi tüm diğer öğelerin birbiriyle karşılıklı etkileşiminde, tek ve eşsiz olan bireyde farklı yanıtlar ortaya çıkarabilmektedir. Bu nedenle olgunun tanılanması, yaşamda bireysellik öğesi doğrultusunda yaşam modelinin tüm öğeleri dikkate alınarak yapılmıştır.

\section{Tartışma}

Akut Tip-A diseksiyonu yüksek cerrahi morbidite ve mortalite ile seyreden bir hastalıktır ve cerrahi sonrası hastane içi 30 günlük mortalite oranı \%8 ile \%25 arasında değişmektedir. ${ }^{[1,3-5]}$ Mortalite ve morbidite riski yüksek bir hastalık olması yoğun bakım süreçlerinin uzaması ve dolayısıyla üst düzey bir yoğun bakım gereksiniminin ortaya çıkmasına yol açmaktadır. Hemşireliğin amacı bireylerin sağlığını korumak, geliştirmek ve hastalık durumunda iyileşmeyi ve bağımsızığı kazanmasına yardım etmektir. Bu amacı yerine getirirken uygulanan hemşirelik bakımının, yüksek riskli ve yüksek bakım gereksinimleri olan hastalara çok daha sistematik, amaçlı ve etkili olması gerekmektedir. Bunu sağlayabilmek için sıklıkla hemşirelik modellerinden yararlanılmaktadır. Literatürde ${ }^{[7,11,16,17]}$ Roper Logan ve Tierney'nin Günlük Yaşam Aktivitelerine Dayalı Hemşirelik Modeli kullanılarak sunulmuş farklı hastalıklara yönelik olgu sunumla- rına rastlanmakla birlikte aort diseksiyonuna yönelik hemşirelik modellerinden yararlanılarak oluşturulmuş bir olgu sunumuna rastlanmamıştır. Bu çalışmada YBÜ'nde yatan Tip-A aort diseksiyonlu bir olgu yaşam aktivitelerine dayalı hemşirelik modeli doğrultusunda incelenmiştir. Yaşam aktivitelerine dayalı hemşirelik modeli bireyi bir bütün olarak ele alması, holistik ve hümanistik yaklaşımla bakımı sağlaması, eğitim ve uygulamaya aktarılmasının kolay olması nedeniyle tercih edilmektedir. Çalışmanın sonucunda yaşam modelinin, aort diseksiyonlu hastanın tanılamasında etkin ve kullanılabilir bir model olarak YBÜ'nde çalışan hemşirelere rehber olacağı düşünülmektedir.

\section{Hakem Değerlendirmesi: Dış bağımsız.}

Çıkar Çatışması: Yazarlar arasında herhangi bir çıkar çatışması bulunmamaktadır.

Bilgilendirilmiş Onam: Olgu sunumunun yayınlanması için yazııı bilgilendirilmiş onam alındı.

Yazarlık Katkıları: Konsept: G.A., Ö.I., Dizayn: G.A., Ö.I., Veri Toplama ve İsleme: G.A., Analiz veya Yorumlama: Ö.l., Literatür Arama: G.A., Ö.I., Yazan: G.A., Ö.I.

\section{Kaynaklar}

1. Göktekin MÇ. A Retrospective Analysis of Patients With Aortic Dissection In The Emergency Unit. [Article in Turkish]. Van Tıp Derg 2019;26:29-33.

2. Aktürk E. Aortic Dissection: Pathogenesis and Clinical Findings. [Article in Turkish] Turkiye Klinikleri Cardiology-Special Topics 2016;9:32-5.

3. Trimarchi S, de Beaufort HW, Tolenaar JL, Bavaria JE, Desai ND, DiEusanio $M$, et al. Acute aortic dissections with entry tear in the arch: A report from the International Registry of Acute Aortic Dissection. J Thorac Cardiovasc Surg 2019;157:66-73.

4. Yang B, Norton EL, Hobbs R, Farhat L, Wu X, Hornsby WE, et al. Short-and long-term outcomes of aortic root repair and replacement in patients undergoing acute type $A$ aortic dissection repair: Twenty-year experience. J Thorac Cardiovasc Surg 2019;157:2125-36.

5. Arslantaş U, Pala S. Endovascular Treatment of the Aortic Dissection. [Article in Turkish]. Turkiye Klinikleri Journal of Cardiology Special Topics 2016;9:43-7.

6. Doran S, Llamas Osorio Y, Murphy M, Kavanagh E, Murphy S. Type A aortic dissection secondary to a left common carotid artery dissection. Radiol Case Rep 2019;14:647-51.

7. Bilgiç Ş, Çelikkalp Ü, Sarıkaya N. Diagnosis of a Necrotizing Faciitis Case According To the Living Model. [Article in Turkish]. Gümüşhane University Journal Of Health Sciences 2017;6:320-5.

8. Pokorny ME. Nursing theorists of historical significance. In: Alligood MR, Tomey AM, editors. Nursing Theorists and Their Work; 7th ed. USA: Mosby Elsevier; 2010. p. 63-65.

9. Roper N, Logan W, Tierney AJ. The elements of nursing a mo- 
del for nursing based on a model of living. 4th ed. Edinburgh, Churchill Livingstone; 1996.

10. Vicdan Kacaroğlu A, Karabacak GB, Alpar Ecevit Ş. Classification of 2012-2014 NANDA-I nursing diagnostics using the Nursing Model Based on Activities of Living. [Article in Turkish]. International Journal of Human Science 2015;12:1626-36.

11. Köşgeroğlu N, Mert Boğa S. Mental Disabled Persons' Issues According to the Daily Life Activities Model (DLAM). Maltepe Üniversitesi Hemşirelik Bilim ve Sanatı Dergisi 2011;4:148-54.

12. Kaya N. Yaşam Modeli. In: Babadağ K, Atabek Aşti T, editors. Hemşirelik Esasları Uygulama Rehberi. 2nd ed. İstanbul:İstanbul Medikal Yayıncılık; 2012. p. 1-7.

13. Moral AR, Uyar M. Yoğun Bakım Hastalarında Nütrsiyon. In: Şahinoğlu AH, Ed, Yoğun bakım Sorunları ve Tedavileri. 3rd ed.
İstanbul: Nobel Tıp Kitabevleri; 2011. p. 525-42.

14. Delaney LJ, Van Haren F, Lopez V. Sleeping on a problem: the impact of sleep disturbance on intensive care patients-a clinical review. Ann Intensive Care 2015;5:3.

15. Pagnucci N, Tolotti A, Cadorin L, Valcarenghi D, Forfori F. Promoting night time sleep in the intensive care unit: alternative strategies in nursing. Intensive Crit Care Nurs 2019;51:73-81.

16. Yüksel Acar C, Yalın H. Thrombotic Thrombocytopenic Purpura and Nursing Care: A Case Study. [Article in Turkish]. Hemşirelikte Eğitim ve Araştırma Dergisi 2016;13:59-66.

17. Bulucu Böyüksoy GD, Demir G, Durmuş H, Dazıroğlu N. Holistic Nursing Care for Hospitalized Type II Diabetes Patient: Case Report. Hacettepe Üniversitesi Hemşirelik Fakültesi Dergisi 2016;3:77-82. 